\title{
Perceptions on the Effects of Auditor-Client Relationship upon Audit Quality and Auditor Independence: Evidence from Bahrain
}

\author{
Hussein Khasharmeh, Abdulqawi A. Hezabr \\ Applied Science University, Accounting and Finance Department, Kingdom of Bahrain
}

\begin{abstract}
The study aims to focus upon the association between the auditors and companies by indicating how this association affects the quality of audit and auditor independence in a developing country (the case of Bahrain). To achieve these objectives, a questionnaire was developed and distributed to respondents from audit firms in Bahrain. Descriptive statistics were used to analyse the influence of auditor-client association upon quality of audit and auditor independence and how audit quality and auditor independence are improved was also explored in the study. The results show that all the questions (1-8) in the questionnaire impair both audit quality and auditor independence with the means ranging from 3.6000 to 4.0364 with an average mean of 3.7212 . According to the measurement scale, any item with a mean of 3.50 or more is acceptable, and since all the influences are above 3.50 , they are all acceptable. Regarding how auditor-client relationship (or long tenured auditor) would improve both quality of audit and auditor independence, the results show that all the questions (9-17) would improve both audit quality and auditor independence with the means ranging from 3.6364 to 4.0727 with an average of 3.8646 , which are acceptable. These results confirm statistically that there is a significant relationship between the auditor long-term tenure and audit quality and auditor independence, so the null hypothesis (H0) is rejected and the alternative hypothesis is accepted. Simple regression analysis is employed to test the hypothesis of the study and its significance. The results show that (H0) hypothesis is not significant. Therefore, the alternative hypothesis (H1) is significant at $p \leq 0.005$, which means that there are differences in viewpoints among respondents and the $p$-value obtained is 0.044 which is less than the significant value of $p \leq 0.05$. These results confirm the hypothesis that a significant relationship exists between the auditor long-term tenure and quality of audit and auditor independence.

Keywords: audit tenure, audit quality, partner tenure, Bahrain, Central Bank of Bahrain (CBB), auditor-client relationship, Gulf Cooperation Council (GCC)
\end{abstract}

\section{Introduction}

There is no great attention devoted to the relationship between auditors and clients. In all countries across the world, audit quality is considered one of the major contributions in terms of supporting their economy, and keeping the country stable. It is important to note that the association between audit tenure and audit quality is not clear enough. Many studies in the literature pointed out that audit quality is negatively related to longer association with a client (DeAngelo, 1981; Deis \& Giroux, 1992; Copley \& Doucet, 1993; O’Keefe, King, \&

Hussein Khasharmeh, Associate Professor, Accounting and Finance Department, Applied Science University. Email: hkhasharmeh@hotmail.com.

Abdulqawi A. Hezabr, Assistant Professor, Accounting and Finance Department, Applied Science University. 
Gaver, 1994). Auditor independence is essential to enhance the confidence in financial statements since it is assumed to reduce or minimize errors in financial statements and ensure that financial statements are prepared in accordance with Generally Accepted Accounting Principles (GAAP). When the auditor becomes able to discover and report the existing material misstatements, the audit process itself becomes more effective and reaches a higher quality. Extended auditor client relationship seems to deter the auditor's capability to achieve high level of conduct to raise audit quality (Hamilton, Ruddock, Stokes, \& Taylor, 2005). Iyer and Rama (2004; as cited in Meyer, Rigsby, \& Boone, 2006, p. 54) believed that "companies have more power over the auditor in the earlier years of engagement".

On the other hand, other empirical studies indicated that audit quality improves with audit tenure. Mansi, Maxwell, and Miller (2004) found that a decline in the cost of debt is decreased with longer auditor tenure (that is, cost of debt is inversely correlated to longer audit tenure).

The association between audit tenure and audit quality is a controversial issue. Many authors believed that the longer the audit tenure, the lower the audit quality (negative association). This may be justified on the ground that the closer association between auditors and management reduces the audit quality (Catanach \& Walker, 1999; Vanstraelen, 2000). This closer association results in more flexibility for management to prepare financial statements in favor of auditors (Davis, Soo, \& Trompeter, 2000). Deis and Giroux (1992) examined audit quality letters published by a public agency and concluded that audit quality decreases as audit tenure increases. J. N. Myers, L. A. Myers, and Omer (2003) found that a lot of determinants were placed by auditors on management with longer auditor tenure, and Geiger and Raghunandan (2002a; 2002b) found that more audit reporting failures occurred in the earlier years of audit tenure.

However, other studies concluded that audit firm tenure may encourage auditors and clients to foster skills of knowledge and understanding of company overtime that may lead to improving audit quality. Longer auditor-client relationship may enhance the auditing firms to develop their experience and maximize credibility with the company. Geiger and Raghunandan (2002a) pointed out that the longer the audit tenure, the higher the audit quality (positive relationship).

Based on the above discussion, the problem statement of the study can be highlighted from the point that the audit function is focused on providing the interested users such as shareholders, creditors, lending institutions, and others for decision-making with reliable financial information. The users must be confident in depending upon the financial information. However, the recent international corporate reporting failures, such as Enron and WorldCom, have raised concerns over the credibility of financial information.

The study aimed to focus upon the association between companies and auditors by indicating how this association affects the quality of audit and auditor independence in a developing country (Bahrain as a case study).

The current study is directed towards giving answer to the following question: How quality of audit in Bahrain is affected by the long-term auditor-client association? And how auditor-client relationship (or long tenured auditor) would improve both audit quality and auditor independence? This study investigates the potential determinants of audit quality and auditor independence in Bahrain.

By fulfilling such objectives, the current study may contribute to the literature in the following issues:

(1) To fill the room in the literature review about auditing issues since little research studies directly examined long-term auditor-client association in developing countries and specifically Gulf Cooperation Council (GCC) countries, the case of Bahrain. Thus, it provides a basis for further research to investigate the issue of audit quality and financial reports and establishes a crucial link for future research; 
(2) To the knowledge of the researchers, the current study may be very new in developing countries that explicitly investigate the influence of auditor-client association upon quality of audit in Bahrain;

(3) The current study is expected to have important references and useful implications for users of financial statements as a contribution to prior studies.

The remainder of this study covers: Section 2 presents the controversy viewpoints about long-term auditor tenure and audit quality association; Section 3 deals with the Bahrain background environment; Section 4 presents methodology; Section 5 presents the statistical analysis; and Section 6 covers summary and conclusions.

\section{Controversy and Literature Review}

In the light of increasing complexity and size of business organizations, external auditors are more likely to help companies in making their decisions (Armstrong, 1987; Chandler \& Edwards, 1996; as cited in Joshi, Al Ajmi, \& Bremser, 2009, p. 267), "to minimize the likelihood of innocent mistakes and deliberate misstatements such as fraud and management manipulations" (Watts \& Zimmerman, 1986; Chandler, Edwards, \& Anderson, 1993).

The auditor-client association poses a risk to the objectivity and auditor independence that might lead to diminishing audit quality; this is because auditor becomes more familiar, and more close to the client. Other arguments favor the view of decreasing audit quality because auditor becomes more close to clients and resulted in diminishing the objectivity and auditor independence (Boone, Khurana, \& Raman, 2008).

To improve financial statements quality, business firms are required to switch their auditors under establishing compulsory rotation of audit firm. Brazil and Italy require their public listed companies to change their auditing firms after a period of five and nine years, respectively (Jackson, Moldrich, \& Roebuck, 2008). They added that compulsory audit firm rotation may not result in increasing audit quality, rather mandatory audit firm rotation results in more cost than benefits. While other authors pointed out that compulsory audit firms rotation would decrease the likelihood of bankrupt companies as it was happened when Enron, WorldCom, and Tyco collapsed.

It is necessary to note that close relationship between the client and auditor leads to boosting auditor-client long-tenured association, which results in the reduction of audit quality, since at the beginning of association, it is difficult to discover important errors that may result in risky to the integrity of financial reports, and thus enhance audit quality with increases of association (Johnson, Khurana, \& Reynolds, 2002; Boone et al., 2008).

In summary, two different arguments between long audit tenure and financial statements quality are available. The first points out that the longer the period of audit tenure, the less audit quality. This is because longer audit tenure leads to closer relationship between auditors and clients. The closer association may cause the auditor and the client to compromise their views regarding auditing and reporting method. This leads to a decrease in the audit quality. The second argument indicated that the longer the period of auditor tenure, the positive audit quality. Therefore, longer auditor tenure resulted in higher audit quality. Regulators have suggested a link between auditor tenure and reductions in earnings quality and recommended imposing such a requirement (Commission on Auditors' Responsibilities, 1978). The positive auditor-client association is due to: (1) more cases of audit failures and lawsuits appeared at the inception of audit engagement. The likelihood of audit failures occurs at the early years of audit period. The study conducted by Geiger and Raghunandan (2002a) showed that audit failures occur at the early audit period and thus, longer audit tenure might enhance audit quality. Carcello and Nagy (2004) stated that fraudulent financial reporting is likely to be higher in case of short audit firm's tenure and is not higher in case of long audit tenure. 
Audit quality is the combination between the auditor's competence and independence. A positive association between auditor's competency and tenure is predicted because the longer the tenure, the higher the auditor's competency since the auditor became familiar with the company's internal control, accounting information system, and specific risks (DeAngelo, 1981).

Based on the above discussions, the following arguments in favor of short auditor-client association may be summarized:

(1) The new auditor would periodically bring a fresh look to the public company's financial reporting and assist the auditors to deal with audit quality issues appropriately;

(2) Short auditor-client association would enhance the development of the auditing profession and the growth of smaller and medium-sized audit firms.

The arguments in favor of long auditor-client association may be:

(1) New auditors may not be aware of issues related to clients since they have short period of engagement with the client to enable them to discover material errors and mistakes;

(2) Short auditor-client association raises the likelihood of audit failure because the newly auditors rely heavily on the estimates and representations of the client in the beginning years of the appointment. This may affect inversely audit quality and effectiveness in the early years;

(3) Short auditor-client association would weaken the audit quality and prevent auditors from establishing institutional knowledge about the client and his business (Shockley, 1981; Meyer et al., 2006).

Since the study aimed to investigate the impact of auditor-client association upon audit quality, it is important to revise the previous studies about audit quality.

\section{Auditor-Client Association}

Johnstone and Muzatko (2002; as cited in Joshi et al., 2009, p. 267) pointed out that:

Auditing firms have to keep the information gathered from clients during the process of conducting external audit secrecy and confidentiality. The auditor must apply professional standards and ethics as a basis for providing unbiased opinion on whether the financial statements are prepared in according to generally accepted auditing standards.

Furthermore, it has been pointed out in the literature that auditors and clients both benefit from a long-term association with each other. Auditors benefit from the valuable knowledge of clients that may help them to prepare effective and efficient audit reports.

In initial years, quality of audit may be affected by the relationship between auditor and client. Carcello and Nagy (2004) found that no evidence proves that if auditor tenure is long, audit quality is impaired.

Myers et al. (2003) found a positive relationship between long audit tenures and higher audit quality. They based their conclusions "on the assumption that longer auditor tenure (five years or greater) leads to stronger relationship between a client and auditor, the stronger the relationship, the greater the knowledge" of auditor, which increases the likelihood that the auditor will issue an unqualified opinion sooner. Davis et al. (2000; as cited in Aamir \& Farooq, 2011, p. 12) pointed out that as "the auditor tenure increases, the management gains additional reporting flexibility".

General Accounting Office (GAO, 2003) indicated that the recent auditor has little knowledge about the issues of "client-firms' operations, information systems, and practices of financial reporting". This makes it time-consuming for auditors to become knowledgeable about the client enabling him to detect important mistakes in the financial statements of the client. 


\section{Auditor Tenure and Audit Quality}

The issue is concerned about how audit quality is affected by long-term tenure. Due to the scandals and economic events, there have been a lot of controversies and fewer agreements regarding the relationship between long-term tenure and quality of audit.

Quality of audit is a vital feature to be considered in evaluating the usefulness of the auditor-client association and short-term audit-client relationship rule. DeAngelo (1981; as cited in Nemhi, Behzad, \& Bazarkhak, 2014, p. 208) defined audit quality as "the probability that an auditor will both discover and truthfully report material errors, misrepresentations, or omissions detected in a client's accounting system". In the same talking, Davidson and Neu (1993; as cited in Nemhi et al., 2014, p. 208) defined audit quality as "the ability of auditor to discover and report material misstatement and manipulated discovery in the net profit". Titman and Trueman (1986; as cited in Nemhi et al., 2014, p. 208) also defined audit quality as "after the accuracy of the information that is available to investors". The following are main factors that can be taken into consideration when evaluating the audit quality (Cameran, Merlotti, \& Di Vincenzo, 2005; as cited in Mostafa \& Hussien, 2010, p. 3):

(1) Performance determinants: They relate to the ability of auditors, intended both as knowledge and experience. (2) Economic incentives: As the audit firm's performance is affected by economic considerations (i.e., fees, costs, profits), these incentives have to be evaluated when analyzing both detection and reporting matters. (3) Audit market structure: The auditor's performance is influenced by professional ethics and the visibility of the profession's enforcement actions.

Geiger and Raghunandan (2002a) stated that there is no association between long auditor tenure and the decline in audit quality but such association exists in the case of short-term audit tenure.

Auditing costs can be affected by location of auditors and quality of audit. It has been suggested in the literature that high costs of non-local auditing motivate clients to change their non-local auditing to local ones, due to the higher costs of travel, transportation, telecommunications, etc.. In this regard, Gul, Kim, and Qiu (2006) indicated that close local auditors can help reduce costs. Local auditors may create closer association and credible contact with companies than created with non-local auditors. In addition, local auditors seem to be more active in getting valuable data from different sources of media about companies (Ball \& Shivakumar, 2005). Thus, comparing non-local with local auditors enhances the flowing of information and communication and may lead to improvement of audit quality and efficient supervision.

It is essential to shed the light upon some of the previous studies about audit quality. Copley and Doucet (1993) examined the relationship between audit quality services and long-term auditor tenure. Findings show a positive association. This indicates that decrease in the risk of audit quality is positively related to the long period of association.

Vanstraelen (2000; as cited in Mostafa \& Hussien, 2010, p. 1) conducted a study about the issue of audit-client association and audit quality. His study found that clients "receiving a clean audit report have a significantly longer relationship with the auditors than companies that receive an unclean report". So, long auditor tenure minimizes the possibility of issuing a qualified report by the auditor. Johnson et al. (2002) investigated the relationship between audit firm tenure and financial reporting quality.

Chi, Huang, and Liao (2004) investigated the relationship between client and audit tenure and its impact upon quality of financial statements. They found that audit tenure has a negative effect on audit quality. However, they found that a longer auditor tenure-client association enhances audit quality.

Meyer et al. (2006) investigated the impact of auditor-client association upon auditor decision. Opinions of auditor's judgments are considered as a constraint to audit quality. 
Fitriany, Utama, Martani, and Rossieta (2009) examined the impact of audit tenure and specialization upon the quality of financial statements. The study concluded that audit firm rotation does not improve audit quality, so it should be discontinued, while audit tenure is still required.

A study conducted by H. Birjandi, M. Birjandi, and Hajizadeh (2013) examined the spatial distance between auditor and client and its influence upon quality of audit on companies listed in Tehran Stock Exchange for the period of 2008-2012. A survey type (questionnaire) was used in the study. ANOVA and correlation coefficient were used in the analysis. The results of the study indicated that with decreasing spatial distance, audit quality would be improved.

Moreover, Nemhi et al. (2014) examined the impact of distance between auditors and clients on the quality of financial statements of companies listed in Tehran Stock Exchange for the period of 2006-2009. ANOVA and coefficient correlation were used in the analysis. The study findings indicated that decreasing distance between the auditor and the client leads to improving financial information.

Thus, there is a need to conduct further studies to stand on the status of how long auditor-tenure affects audit quality. Thus, the current study is expected to contribute partially to the literature and minimize this gap.

\section{The Bahrain Background Environment}

In 2008, 24 auditing firms were established in Bahrain. These auditing firms were distributed as follows: five local, four as foreign branches, and the remaining are linked to international forms.

Recently, audit process has been considered as vital for political stability and investment standards. However, in developing countries like Bahrain, audit activities have addressed challenges related to the economic environment. According to Joshi et al. (2009, p. 275):

Bahrain environment is featured as emerging capital market dominated by large government and family ownership of listed firms, powerful regulations of the audit environment, strong auditors, and no public records of government actions taken against auditors. The formal strategy is to improve the ease of business registration. This is being insured through Bahrain Investors Centers located at places when business persons can have easy access. An effective anti-trust system to foster competition and unfair trade practices is being put in place. The quality and consistency of regulators is being reviewed periodically. Commercial and industrial laws have been reviewed and improved. The revised Commercial Companies Law aims to overcome obstacles in establishing businesses, simplifying legal and administrative procedures and laying down principles of corporate governance.

In the light of the increasing focus on the stock exchange market of Bahrain as an important avenue for attracting foreign investments and to encourage local residents to invest in. Bahraini companies' shares may engage in mandatory audit firm rotation as a means to enhance the quality of audit, and this may promote "the company's ability to raise capital at the lowest possible cost" (Healy \& Palepu, 1993; Lev, 1992; as cited in Andrew, 2015, p. 98).

This issue is chosen based on the notion of how quality of audit can be affected by long-term audit tenure. The motivation of the current study stems from a number of reasons. First, most of the previous studies on auditor-client association were conducted in developed countries, unlike the current study is applied in developing countries, the case of Bahrain. Second, to the best knowledge of researchers, no such study was carried out with a special reference to Bahrain. The results of this study are expected to expand knowledge about how audit-client relationships in Bahrain affect the quality of financial statements. Third, Bahrain as a member of GCC countries shares a number of specific economic characteristics such as high dependency on oil and the heavy dependence on expatriate labor in the private sector, and this may help GCC countries to benefit from the findings of this study. 


\section{Research Methodology}

\section{Development of Research Hypotheses}

To meet the aims of the study and in the light of the conclusions reached from previous studies, together with what have been discussed above regarding Bahrain auditing environment, the following research hypotheses were formulated for the current study:

H01: There is no significant relationship between long-term auditor tenure and audit quality and auditor independence (Questions 1-8 in the questionnaire testing this hypothesis).

H02: There is no significant relationship between demographic variables (experience and profession) and audit quality and auditor independence.

\section{Population and Sample of Study}

The population of this study consists of all auditors who are working in audit firms in Bahrain. Bryman and Bell (2007, p. 179) pointed out that "the suitable selection of sample is important for the reliability of the research". The sample consists of respondents from audit firms in Bahrain. Thirty questionnaires were distributed personally and via e-mail to auditors selected from the big three audit firms in Bahrain (PWC, Ernest and Young, and KPMG) and 22 questionnaires were received with a response rate of $73.3 \%$.

\section{Data Collection}

Two main sources (primary and secondary) were utilized to collect data for the current study. Primary source of data is derived from using survey, whereas secondary source of data is related to published materials and articles, books, research papers in journals and data extracted from the web about the subject area.

To achieve the objectives of this study and in the light of literature review and theoretical background, a questionnaire was developed. The questionnaire comprises two parts. Part one contains some demographic information, while part two includes questions about the perceptions on the influences of auditor-client relationship upon audit quality and auditor independence, and would improve both audit quality and auditor independence.

Table 1

Details of Questions Used in the Current Survey

\begin{tabular}{|l|l|}
\hline Questions \\
\hline Group 1: Auditor-client relationship (or long tenured auditor) would impair both audit quality and auditor independence. \\
\hline 1 & $\begin{array}{l}\text { Longer auditor tenure impairs both the quality of auditor performance in the auditing process and the independence of } \\
\text { the auditor. }\end{array}$ \\
\hline 2 & $\begin{array}{l}\text { Longer auditor tenure makes the auditor with a non-renewable look to examine the accounts of the clients. This leads to } \\
\text { decline of the quality of his performance in the review process and reduces auditor independence. }\end{array}$ \\
\hline 3 & $\begin{array}{l}\text { Longer auditor tenure makes the auditor repeat of earlier engagements which foster the tendency of anticipating the } \\
\text { results. This may reduce the quality of his performance and reduce auditor independence. }\end{array}$ \\
\hline 4 & $\begin{array}{l}\text { Longer auditor tenure makes the auditor depend on the same papers and documents prepared by the client, so his } \\
\text { performance lacks the quality in the auditing process and auditor independence is reduced. }\end{array}$ \\
\hline 5 & $\begin{array}{l}\text { Longer auditor tenure makes the auditor loss the most important qualities by which he should be characterized, namely, } \\
\text { professional audit. Thus, his performance lacks the quality in the audit process and auditor independence is reduced. }\end{array}$ \\
\hline 6 & $\begin{array}{l}\text { Longer auditor tenure leads to the possibility of containing the financial statements with mistakes (he did not discover). } \\
\text { So, his performance lacks the quality in the audit process and auditor independence is reduced. }\end{array}$ \\
\hline 7 & $\begin{array}{l}\text { Longer auditor tenure makes the auditor slack in his work. This increases the opportunity of not detecting the } \\
\text { unintentional mistakes. Thus, performance in the audit process lacks the audit quality and reduces auditor independence. }\end{array}$ \\
\hline 8 & $\begin{array}{l}\text { Longer auditor tenure leads to an increase of the risk that the auditor losses his performance and objectivity, which } \\
\text { ultimately leads to lower quality of his performance in the audit process and reduces auditor independence. }\end{array}$ \\
\hline
\end{tabular}


(Table 1 continued)

\begin{tabular}{|l|l|}
\hline \multicolumn{2}{|l|}{ Questions } \\
\hline Group 2: Auditor-client relationship (or long tenured auditor) would improve both audit quality and auditor independence. \\
\hline 9 & Longer auditor tenure reduces the possibility of issuing a qualified report by the auditor. \\
\hline 10 & $\begin{array}{l}\text { Longer auditor tenure increases the experience and knowledge of the auditor about company's operations, which may } \\
\text { result in a higher audit quality and improve auditor independence. }\end{array}$ \\
\hline 11 & $\begin{array}{l}\text { Longer auditor tenure of 5-10 years is more likely to detect material errors than those with 0-5 years' experience with the } \\
\text { client. }\end{array}$ \\
\hline 12 & $\begin{array}{l}\text { Audit failure is more risky in the early years of an audit tenure period, as the new auditor has not fully developed and } \\
\text { understood in-depth the new client's operations and financial reporting practices and this will impair audit quality and } \\
\text { reduce auditor independence. }\end{array}$ \\
\hline 13 & $\begin{array}{l}\text { Audit failure is more risky in the early years of an audit tenure period, because the new auditor relies heavily upon } \\
\text { information provided by client management. }\end{array}$ \\
\hline 14 & $\begin{array}{l}\text { Audit failure tends to increase as the audit tenure period increases since the client becomes more familiar with the } \\
\text { auditor's approach and procedures. }\end{array}$ \\
\hline 15 & $\begin{array}{l}\text { In the long-tenured auditor, the audit quality may be enhanced because clients' operations and reporting matters become } \\
\text { much familiar and known to the auditor. }\end{array}$ \\
\hline 16 & $\begin{array}{l}\text { In early years, because the auditor is new to the client and has little knowledge about the client's business and accounting } \\
\text { policies and systems, the audit quality is expected to be low. }\end{array}$ \\
\hline 17 & $\begin{array}{l}\text { Longer auditor tenure results in an increase in the knowledge of an auditor regarding the client company, which then } \\
\text { enhances audit and results in good quality of audit. }\end{array}$ \\
\hline
\end{tabular}

Table 1 above includes details on the 17 questions in Section 2 of the questionnaire. These questions were measured using a 5-point Likert scale ranging from 1 to 5 , where 1 refers to strongly disagree and 5 refers to strongly agree. One open-ended question was also asked to gather the views of the respondents on the issue of the study (A copy of the questionnaire is available upon request).

\section{Validity of Study Tool}

To prove the validity of the study tool, we gave copies of the questionnaire to many accounting professors in Bahrain University and other universities both in and outside Bahrain. Also, copies of the questionnaire were given to auditing professionals in Bahrain. In addition, the questionnaire is given to some academic professors who are specialized in statistics. All their notes and comments were taken into consideration before finalizing the questionnaire.

\section{Data Analysis}

\section{Internal Consistency of the Questionnaire's Reliability}

According to Bryman and Cramer (2001, p. 78):

The internal consistency of the questionnaire's reliability was measured by using Cronbach's coefficient alpha statistical test as shown in Table 2 below. The analysis in the table provides an indication of the average correlation among all the items that made up the scale. The results demonstrate that all indices obtained regarding questions related to auditors were considered to be high (above 0.70). A sample scale that shows an alpha value above 0.70 is considered as reliable. Therefore, the indices for the questionnaire's reliability are generally considered as adequate for this research.

Table 2

Reliability Test

\begin{tabular}{ll}
\hline Questions & Cronbach's alpha \\
\hline Questions 1-8 & 0.902 \\
Questions 9-17 & 0.771 \\
\hline
\end{tabular}




\section{Demographic Analysis}

Table 3 below shows the analysis regarding demographic information. The results in the table show that $73 \%$ of the respondents are specialized in accounting followed by $18 \%$ economics and $9 \%$ finance. These results imply that respondents are qualified enough to answer the questions and provide reliable information.

Table 3

Demographic Analysis

\begin{tabular}{|c|c|c|}
\hline & Frequency & Percent (\%) \\
\hline \multicolumn{3}{|l|}{ Specialization } \\
\hline Accounting & 16 & 73 \\
\hline Finance & 2 & 9 \\
\hline Economics & 4 & 18 \\
\hline Others & 0 & 0 \\
\hline \multicolumn{3}{|l|}{ Gender } \\
\hline Male & 18 & 82 \\
\hline Female & 4 & 18 \\
\hline \multicolumn{3}{|l|}{ Experience } \\
\hline 1-less than 5 years & 8 & 36 \\
\hline 5-less than 10 years & 4 & 18 \\
\hline Over 10 years & 10 & 46 \\
\hline \multicolumn{3}{|l|}{ Age } \\
\hline less than 20 years & 0 & 0 \\
\hline 20 -less than 30 years & 12 & 55 \\
\hline 30-less than 40 years & 8 & 36 \\
\hline 40 years and above & 2 & 9 \\
\hline \multicolumn{3}{|l|}{ Professional } \\
\hline $\mathrm{CPA}$ & 6 & 27 \\
\hline CIMA & 0 & 0 \\
\hline Others such as ACCA & 16 & 73 \\
\hline \multicolumn{3}{|c|}{ Long-term auditor tenure } \\
\hline 1-less than 5 years & 16 & 73 \\
\hline 5-less than 10 years & 2 & 9 \\
\hline Over 10 years & 4 & 18 \\
\hline
\end{tabular}

Regarding the gender variable, the results show that $82 \%$ of the respondents are male and $18 \%$ are female. It seems that auditing profession is difficult for female since it requires the auditor to travel to companies in their locations and spend long time in auditing process and thus, this profession may not be suitable for female. Thus, the results are not surprised.

Concerning the experience variable, the table shows that $64 \%$ have experience of more than five years in audit profession that may be reflected upon the reliability of information provided by them and in turn, will positively be reflected upon the quality of the information provided by the respondents.

Regarding the age variable, the results show that $91 \%$ of the respondents are between 20 and 40 years age. This means that most of the respondents are matured and young and can provide valuable information to be used in the analysis which may be reflected positively upon the results of the study.

Regarding the professional certificates, the results show that all the respondents have professional certificates such as CPA and ACCA. This means that the respondents are qualified enough to provide important information that can be used to generalize the study conclusions. 
Concerning the client-auditor relationship, the results in the table show that most of the auditors $(73 \%)$ have less than five years' relationship with clients.

\section{Descriptive Analysis}

Descriptive statistics related to the influence of auditor-client relationship upon audit quality and auditor independence and how audit quality and auditor independence are improved are employed in the study and shown in Table 4 below. The results in the table show that all the Questions (1-8) impair both audit quality and auditor independence with the means ranging from 3.6000 to 4.0364 and standard deviation from 0.59628 to 0.90192. Since standard deviation for all items is less than half of the mean, this means that there is no dispersion among respondents' opinions about the questions of the study. According to the measurement scale, any item with a mean of 3.50 or more is acceptable, and since all the influences get a score of above 3.50 , they are all acceptable. Also, the average mean for all items is 3.7211, which confirms the results concluded above. Regarding how auditor-client relationship (or long-tenured auditor) would improve both audit quality and auditor independence, the results in the table show that all the items (9-17) would lead to improving both audit quality and auditor independence, with the means ranging from 3.6364 to 4.0727 and standard deviation from 0.54309 to 0.84686 . According to the measurement scale, any item with a mean of 3.50 or more is acceptable and since all the influences get above 3.50, all ways of improvement are acceptable. Also, the average mean for all items is 3.8646 , which confirms the results concluded above.

Table 4

Descriptive Analysis of the Influences upon Audit Quality and Auditor Independence and the Possible Means of Improvement

\begin{tabular}{|c|c|c|c|c|c|}
\hline Questions & $N$ & Minimum & Maximum & Mean & Std. deviation \\
\hline \multicolumn{6}{|c|}{ Auditor-client relationship (or long-tenured auditor) would impair both audit quality and auditor independence. } \\
\hline 1 & 22 & 1.00 & 5.00 & 4.0364 & 0.90192 \\
\hline 2 & 22 & 2.00 & 5.00 & 3.6364 & 0.72937 \\
\hline 3 & 22 & 2.00 & 5.00 & 3.6545 & 0.77503 \\
\hline 4 & 22 & 2.00 & 5.00 & 3.7636 & 0.81567 \\
\hline 5 & 22 & 2.00 & 5.00 & 3.6182 & 0.82756 \\
\hline 6 & 22 & 2.00 & 5.00 & 3.6909 & 0.81360 \\
\hline 7 & 22 & 3.00 & 5.00 & 3.6909 & 0.60470 \\
\hline 8 & 22 & 3.00 & 5.00 & 3.6000 & 0.59628 \\
\hline \multicolumn{6}{|c|}{ Average mean $=3.7211$} \\
\hline \multicolumn{6}{|c|}{ Auditor-client relationship (or long-tenured auditor) would improve both audit quality and auditor independence. } \\
\hline 9 & 22 & 2.00 & 5.00 & 4.0727 & 0.71633 \\
\hline 10 & 22 & 3.00 & 5.00 & 3.8182 & 0.69631 \\
\hline 11 & 22 & 2.00 & 5.00 & 3.6364 & 0.84686 \\
\hline 12 & 22 & 2.00 & 5.00 & 3.7818 & 0.68559 \\
\hline 13 & 22 & 2.00 & 5.00 & 3.8545 & 0.80319 \\
\hline 14 & 22 & 2.00 & 5.00 & 3.8000 & 0.77936 \\
\hline 15 & 22 & 2.00 & 5.00 & 4.0364 & 0.54309 \\
\hline 16 & 22 & 2.00 & 5.00 & 3.9273 & 0.79009 \\
\hline 17 & 22 & 2.00 & 5.00 & 3.8545 & 0.70496 \\
\hline
\end{tabular}




\section{Correlations Test}

A correlation test was made (as shown in Table 5 below) to identify whether there is a correlation between the impairment influences and the improvements of such influences. The results show that there is a significant positive relationship between the two groups at $p \leq 0.05$ which means that there is a difference in viewpoints among the respondents.

Table 5

Correlations Test

\begin{tabular}{llcc}
\hline & & Total_impair & Total_improve \\
\hline \multirow{3}{*}{ Total_impair } & Pearson correlation & 1 & $0.533^{*}$ \\
& Sig. (2-tailed) & & 0.011 \\
& $N$ & 22 & 22 \\
\hline \multirow{3}{*}{ Total_improve } & Pearson correlation & $0.533^{*}$ & 1 \\
& Sig. (2-tailed) & 0.011 & \\
& $N$ & 22 & 22 \\
\hline
\end{tabular}

Note. ": Correlation is significant at the 0.05 level (2-tailed).

Table 6

Kruskal-Wallis Test

\begin{tabular}{|c|c|c|c|}
\hline & Experience & $N$ & Mean rank \\
\hline \multirow{4}{*}{ Total_impair } & 1-less than 5 years & 8 & 13.00 \\
\hline & 5 -less than 10 years & 12 & 10.17 \\
\hline & Over 10 years & 2 & 13.50 \\
\hline & Total & 22 & \\
\hline \multirow{4}{*}{ Total_improve } & 1-less than 5 years & 8 & 12.63 \\
\hline & 5 -less than 10 years & 12 & 10.17 \\
\hline & Over 10 years & 2 & 15.00 \\
\hline & Total & 22 & \\
\hline Test statistics & Total_impair & Total_improve & \\
\hline Chi-square & 1.134 & 1.344 & \\
\hline df & 2 & 2 & \\
\hline \multirow[t]{2}{*}{ Asymp. Sig. } & 0.567 & 0.511 & \\
\hline & Professional & $N$ & Mean rank \\
\hline \multirow{4}{*}{ Total_impair } & $\mathrm{CPA}$ & 7 & 10.71 \\
\hline & CIMA & 8 & 13.50 \\
\hline & Others & 7 & 10.00 \\
\hline & Total & 22 & \\
\hline \multirow{4}{*}{ Total_improve } & $\mathrm{CPA}$ & 7 & 13.64 \\
\hline & CIMA & 8 & 12.06 \\
\hline & Others & 7 & 8.71 \\
\hline & Total & 22 & \\
\hline Test statistics & Total_impair & Total_improve & \\
\hline Chi-square & 1.248 & 2.137 & \\
\hline df & 2 & 2 & \\
\hline Asymp. sig. & 0.536 & 0.344 & \\
\hline
\end{tabular}




\section{Kruskal-Wallis Test}

A Kruskal-Wallis test was employed in the study (as shown in Table 6 above) to identify whether there are statistical significant differences between demographic variables (experience and professionalism) and impairment influences. The results show no statistical significant differences for both variables, which means that there is no difference in viewpoints among the respondents.

\section{Hypothesis Test}

Simple regression analysis is employed to test the hypothesis of the study and its significance. The results in Table 7 show that (H01) hypothesis is not significant at $p \leq 0.05$. Therefore, the alternative hypothesis (H1) is significant at $p \leq 0.05$ which means that there is a difference in viewpoints among the respondents, and the $p$-value obtained is 0.044 which is less than the value of significance of $p \leq 0.050$. Thus, the results confirm the hypothesis that there is a significant relationship between the auditor long-term tenure and audit quality and auditor independence.

Table 7

Hypothesis Test

\begin{tabular}{|c|c|c|c|c|c|c|}
\hline \multirow[t]{2}{*}{ Model } & & \multicolumn{2}{|c|}{$\begin{array}{l}\text { Unstandardized } \\
\text { coefficients }\end{array}$} & \multirow{2}{*}{$\begin{array}{l}\text { Standardized } \\
\text { coefficients } \\
\text { Beta }\end{array}$} & \multirow[t]{2}{*}{$t$} & \multirow[t]{2}{*}{ Sig. } \\
\hline & & B & Std. error & & & \\
\hline \multirow{2}{*}{1} & (Constant) & 2.805 & 0.524 & & 5.355 & 0.000 \\
\hline & Auditor to client overall & -0.291 & 0.142 & -0.231 & -2.045 & 0.044 \\
\hline
\end{tabular}

\section{Conclusions}

The findings indicated that there is a significant relationship between the auditor long-term tenure and audit quality and auditor independence. The results also show that auditor-client relationship (or long-tenured auditor) would improve both audit quality and auditor independence, the results in Table 4 show all items (9-17) of the questionnaire with the means ranging from 3.6364 to 4.0727 and standard deviation from 0.54309 to 0.84686 .

The average mean of all questions together of the hypothesis is 3.7212 with the average standard deviation of less than half of the mean. This means that there is no dispersion among the respondents about the questions of the hypothesis. Also, the average mean of all questions regarding improvement of audit quality and audit independence as shown in Table 4 is 3.8646 with the average standard deviation of less than half of the mean. This also indicated that there is no dispersion among the respondents about the questions and the $p$-value obtained is 0.044 , which is less than the value of significance at $p<0.050$. These results confirm that there is a statistically significant relationship. Thus, the null hypothesis is rejected and the alternative hypothesis is significant at $p \leq 0.05$ and is thus accepted. Also, the results of Kruskal-Wallis test show that there is no statistically significant relationship between demographic variables and impairment of audit quality and auditor independence.

However, a number of limitations may be encountered in the current study. First, the study is related to auditing firms located in Bahrain, and it does not represent the unlisted and listed companies on the Bahraini financial market. Second, the findings of such a study may not be generalized to different countries with different business environments and cultures. Future research studies about this topic for different countries 
with developing markets might be useful. Therefore, it would be important to conduct this study in other GCC countries or countries in the region. Third, as this study focused on impairment on audit quality and auditor independence and possible means for improvements in Bahrain, further research may be directed towards examining the cost of audit quality. However, factors not included in the study may also impair audit quality and auditor independence. Despite these limitations, the researchers believed that this study has added value to our standings of impairments of audit quality and auditor independence in Bahrain.

\section{References}

Aamir, S., \& Farooq, U. (2011). Auditor client relationship and audit quality (Master thesis, UMEA School of Business at Umea University).

Andrew, K. K. (2015). Effect of corporate attributes on international financial reporting standards disclosure level. Evidence from Kenya listed firms. Research Journal of Finance and Accounting, 6(1), 97-107.

Armstrong, P. (1987). The rise of accounting controls in British capitalist enterprises. Accounting, Organizations and Society, 12(5), 415-436.

Ball, R., \& Shivakumar, L. (2005). The role of accruals in asymmetrically timely gain and loss recognition. University of Chicago.

Birjandi, H., Birjandi, M., \& Hajizadeh, G. R. (2013). Spatial distance between auditor and client and its impact on audit quality on companies listed in Tehran Stock Exchange. International Journal of Economics, Business and Finance, 1(11), 409-419.

Boone, J. P., Khurana, I. K., \& Raman, K. K. (2008). Audit firm tenure and the equity risk premium. Journal of Accounting, Auditing \& Finance, 23(1), 115-140.

Bryman, A., \& Bell, E. (2007). Business research methods (2nd ed.). New York, NY: Oxford University Press.

Bryman, A., \& Cramer, D. (2001). Quantitative data analysis with SPSS release 10 for Windows: A guide for social scientists. London: Routledge.

Cameran, M., Merlotti, E., \& Di Vincenzo, D. (2005). The audit firm rotation rule: A review of the literature. SDA Bocconi Research Paper. Retrieved from http://ssrn.com/abstract +825404

Carcello, J. V., \& Nagy, A. L. (2004). Audit firm tenure and fraudulent financial reporting. Auditing: A Journal of Practice and Theory, 23(2), 55-69.

Catanach, A. H., \& Walker, P. (1999). The international debate over mandatory auditor rotation: A conceptual framework. Journal of International Accounting, Auditing and Taxation, 8(1), 43-66.

Chandler, R. A., Edwards, J. R., \& Anderson, M. (1993). Change perceptions of the role of the company auditor, 1840-1940. Accounting and Business Research, 23(92), 443-459.

Chandler, R., \& Edwards, J. R. (1996). Recurring issues in auditing: Back to the future? Accounting, Auditing and Accountability Journal, 9(2), 4-29.

Chi, W., Huang, H., \& Liao, Y. (2004). Client importance, auditor-client relationship, and abnormal accruals: An audit-partner based investigation. National Chengchi University, China; National Taiwan University and National Chengchi University.

Commission on Auditors' Responsibilities. (1978). Report, conclusions, and recommendations. AICPA.

Copley, P. A., \& Doucet, M. S. (1993). Auditor tenure, fixed fee contracts, and the supply of substandard single audits. Public Budgeting and Finance, 13(3), 23-35.

Davidson, R. A., \& Neu, D. (1993). A note on the association between audit firm size and audit quality. Contemporary Accounting Research, 9(2), 479-488.

Davis, L. R., Soo, B., \& Trompeter, G. (2000). Auditor tenure, auditor independence and earnings management. Working Paper, Boston College.

DeAngelo, L. E. (1981). Auditor size and audit quality. Journal of Accounting and Economics, 3(3), 183-199.

Deis, D. R., \& Giroux, G. A. (1992). Determinants of audit quality in the public sector. The Accounting Review, 67(3), $462-479$.

Fitriany, Utama, S., Martani, D., \& Rossieta, H. (2009). Do mandatory audit firm and audit partner rotation really improve audit quality? Comparison between pre and post regulation period in Indonesia. Retrieved from http://www.rieb.kobe-u.ac.jp/tjar/conference/2nd/CONCURRENT_B_2.pdf

Geiger, M. A., \& Raghunandan, K. (2002a). Auditor tenure and audit reporting failures. Auditing: A Journal of Practice and Theory, 21(1), 67-78. 
Geiger, M. A., \& Raghunandan, K. (2002b). Going-concern opinions in the "new" legal environment. Accounting Horizons, 16(1), $17-26$.

General Accounting Office [GAO]. (2003). Public accounting firms: Required study on the potential effects of mandatory audit firm rotation. Washington, DC: General Accounting Office.

Gul, F. A., Kim, J. B., \& Qiu, A. (2006). Does the political economy affect auditor incentives? Some Chinese evidence on non Big 4 audit quality. Working Paper, Hong Kong Polytechnic University.

Hamilton, J., Ruddock, C., Stokes, D., \& Taylor, S. (2005). Audit partner rotation, earnings quality and earnings conservatism. Working Paper. Retrieved from http://papers.ssrn.com/so13/papers.cfm?abstract_id=740846

Healy, P. M., \& Palepu, K. G. (1993). The effect of firms' financial disclosure strategies on stock prices. Accounting Horizons, $7(1), 1-11$.

Iyer, V. M., \& Rama, D. V. (2004). Clients' expectations on audit judgments: A note. Behavioral Research in Accounting, 16(1), 63-74.

Jackson, A. B., Moldrich, M., \& Roebuck, P. (2008). Mandatory audit firm rotation and audit quality. Managerial Auditing Journal, 23(5), 420-437.

Johnson, V., Khurana, I. K., \& Reynolds, J. K. (2002). Audit-firm tenure and the quality of financial reports. Contemporary Accounting Research, 19(4), 637-660.

Johnstone, K. M., \& Muzatko, S. R. (2002). Resolving difficult accounting issues: A case study in client-auditor interaction. Issues in Accounting Education, 17(1), 27-39.

Joshi, P. L., Al Ajmi, J., \& Bremser, W. G. (2009). A study of auditor-client relationships and problems in the Bahraini audit environment. Advances in Accounting, Incorporating Advances in International Accounting, 25(2), 266-277.

Lev, B. (1992). Information disclosure strategy. California Management Review, 34(4), 9-32.

Mansi, S. A., Maxwell, W. F., \& Miller, D. P. (2004). Does auditor quality and tenure matter to investors? Evidence from the bond market. Journal of Accounting Research, 42(4), 755-793.

Meyer, M. J., Rigsby, J. T., \& Boone, J. (2006). The impact of auditor-client relationships on the reversal of first-time audit qualifications. Managerial Auditing Journal, 22(1), 53-79.

Mostafa, D., \& Hussien, M. (2010). The impact of auditor rotation on the audit quality: A field study from Egypt. Working Paper No. 23, November, German University in Cairo.

Myers, J. N., Myers, L. A., \& Omer, T. C. (2003). Exploring the term of the auditor-client relationship and the quality of earnings: A case for mandatory auditor rotation. The Accounting Review, 78(3), 779-799.

Nemhi, E. A., Behzad, F., \& Bazarkhak, S. (2014). The relationship between auditors and clients, and its effect on the quality of auditing in accepted companies in Tehran Stock Exchange. International Research Journal of Management Sciences, 2(7), 207-215.

O’Keefe, T. B., King, R. D., \& Gaver, K. M. (1994). Audit fees, industry specialization, and compliance with GAAS reporting standards. Auditing: A Journal of Practice and Theory, 13(2), 41-55.

Shockley, R. A. (1981). Perceptions of auditors' independence: An empirical analysis. The Accounting Review, 56(4), 785-800.

Titman, S., \& Trueman, B. (1986). Information quality and the valuation of new issues. Journal of Accounting and Economics, $8(2), 159-172$.

Vanstraelen, A. (2000). Impact of renewable long-term audit mandates on audit quality. The European Accounting Review, 9(3), 419-442.

Watts, R. L., \& Zimmerman, J. L. (1986). Positive accounting theory. Englewood Cliff, NJ: Prentice Hall. 